University of Nebraska - Lincoln

DigitalCommons@University of Nebraska - Lincoln

1981

\title{
Late Quaternary Environmental History of Lake Valencia, Venezuela
}

\author{
J. Platt Bradbury \\ B. Leyden \\ M. Salgado-Labouriau \\ W. M. Lewis Jr. \\ C. Schubert
}

See next page for additional authors

Follow this and additional works at: https://digitalcommons.unl.edu/usgsstaffpub

Part of the Earth Sciences Commons

Bradbury, J. Platt; Leyden, B.; Salgado-Labouriau, M.; Lewis, W. M. Jr.; Schubert, C.; Binford, M. W.; Frey, D. G.; Whitehead, D. R.; and Weibezahn, F. H., "Late Quaternary Environmental History of Lake Valencia, Venezuela" (1981). USGS Staff -- Published Research. 290.

https://digitalcommons.unl.edu/usgsstaffpub/290

This Article is brought to you for free and open access by the US Geological Survey at DigitalCommons@University of Nebraska - Lincoln. It has been accepted for inclusion in USGS Staff -- Published Research by an authorized administrator of DigitalCommons@University of Nebraska - Lincoln. 


\section{Authors}

J. Platt Bradbury, B. Leyden, M. Salgado-Labouriau, W. M. Lewis Jr., C. Schubert, M. W. Binford, D. G. Frey, D. R. Whitehead, and F. H. Weibezahn 


\title{
Late Quaternary Environmental History of Lake Valencia, Venezuela
}

\author{
J. Platt Bradbury, B. Leyden, M. Salgado-Labouriau \\ W. M. Lewis, Jr., C. Schubert, M. W. Binford, D. G. Frey \\ D. R. Whitehead, F. H. Weibezahn
}

In the last decade it has become apparent that the unglaciated equatorial regions of the earth experienced dry climates during the major glaciations of the Pleistocene. In the Western Hemisphere, evidence has come largely from investigations of marine sediments in the Caribbean (1). Less information is avail-

environments at the onset of the Holocene.

Lake Valencia is located near the north coast of Venezuela in a tectonic depression between the Cordillera de la Costa to the north and the Serrania del Interior to the south (Fig. 1). The present lake has a surface elevation of 402 me-

Summary. Chemical, paleontological, and mineralogical analyses of a 7.5-meter core from the middle of Lake Valencia, Venezuela, have provided information on the paleoclimatic history of this low-elevation, low-latitude site for the last 13,000 years. The data show that dry climates existed in this region from 13,000 years before present (B.P.) until about 10,000 years B.P. The Lake Valencia Basin was occupied by intermittent saline marshes at that time. About 10,000 years B.P., a permanent lake of fluctuating salinity formed and arboreal plant communities replaced the earlier dominant xeric herbaceous vegetation and marsh plants. By 8500 years B.P., Lake Valencia reached moderate to low salinities and discharged water; the modern vegetation became established at that time. After 8500 years B.P., the lake twice ceased discharging as a result of reduced watershed moisture. The second of these drying episodes is still in progress and has been aggravated by human activities in the watershed.

able from the terrestrial environment, although geomorphic and palynological studies have provided tentative evidence of pre-Holocene dry climates in the equatorial zone of South America (2). We report here the results of an investigation of the Quaternary sediments from Lake Valencia, Venezuela, that, in conjunction with a detailed radiocarbon chronology, confirm the notion of dry Pleistocene climates in the tropics and chronicle the transition to more humid ters, an area of 350 square kilometers, and a maximum depth of $40 \mathrm{~m}$. The lake is presently endorheic (nondischarging), with a spill point at $427 \mathrm{~m}$.

Lake Valencia has been endorheic and steadily desiccating for more than 200 years. It was last reported to have reached its outlet and drained southward across the interior llanos of Venezuela into the Orinoco River in the early. 18th century (3). Since that time, the lake has become increasingly saline. Past explanations for this present desiccation range from agricultural and industrial use of the water to climatic control of groundwater flow into the lake (4).

Earlier changes in the lake level are recorded in terms of undated lacustrine sediments and lakeshore terraces above the present lake level (5). We have midHolocene radiocarbon dates [about 5500 and 7100 years before present (B.P.)] on two stromatolite beds, which indicate shallow water, at elevations corresponding to two of the terrace levels (418 and $421 \mathrm{~m}$ ). These deposits indicate that the present desiccation was preceded by several earlier desiccation episodes. Further chronological information is available where terraces and lake deposits are associated with archeological remains and from sediment chemistry $(6,7)$.

Lake Valencia has an extensive sediment record that may date to the midTertiary. Seismic investigations in the upper 80 to $100 \mathrm{~m}$ of lake sediments indicate at least three stratigraphic units and also suggest that Holocene faulting may have affected shorelines to some extent (8).

The steep elevational gradient of the surrounding mountains places a number of vegetational zones in close proximity to the lake. These zones range from savanna and decíduous associations near the lake through semideciduous and evergreen forests on mountain slopes and cloud forest on the northern peaks (Fig. 2 ). The vegetation at lower elevations is modified by extensive human disturbance. The Valencia region is of interest as a possible Pleistocene refugium for mesophytic taxa (9). The paleoecological data from the Valencia Basin are important in verifying whether mesic condi-

Dr. Bradbury is a geologist at the U.S. Geological Survey, Denver, Colorado 80225. Drs. Frey and Whitehead are professors of biology at Indiana University, Bloomington. Dr. Leyden is associated with the University of Southern Florida, Tampa. Drs. Salgado-Labouriau and Schubert are with the Instituto Venezolano de Investigaciones Cientificas, Caracas, Venezuela. Dr. Lewis is professor of environmental. population, and organismic biology at the University of Colorado, Boulder. Dr. Binford is a research associate at the Florida State Museum, University of Florida, Gainesville. Dr. Weibezahn is with the Escuela de Biologia, Universidad Central, Caracas, Venezuela. 

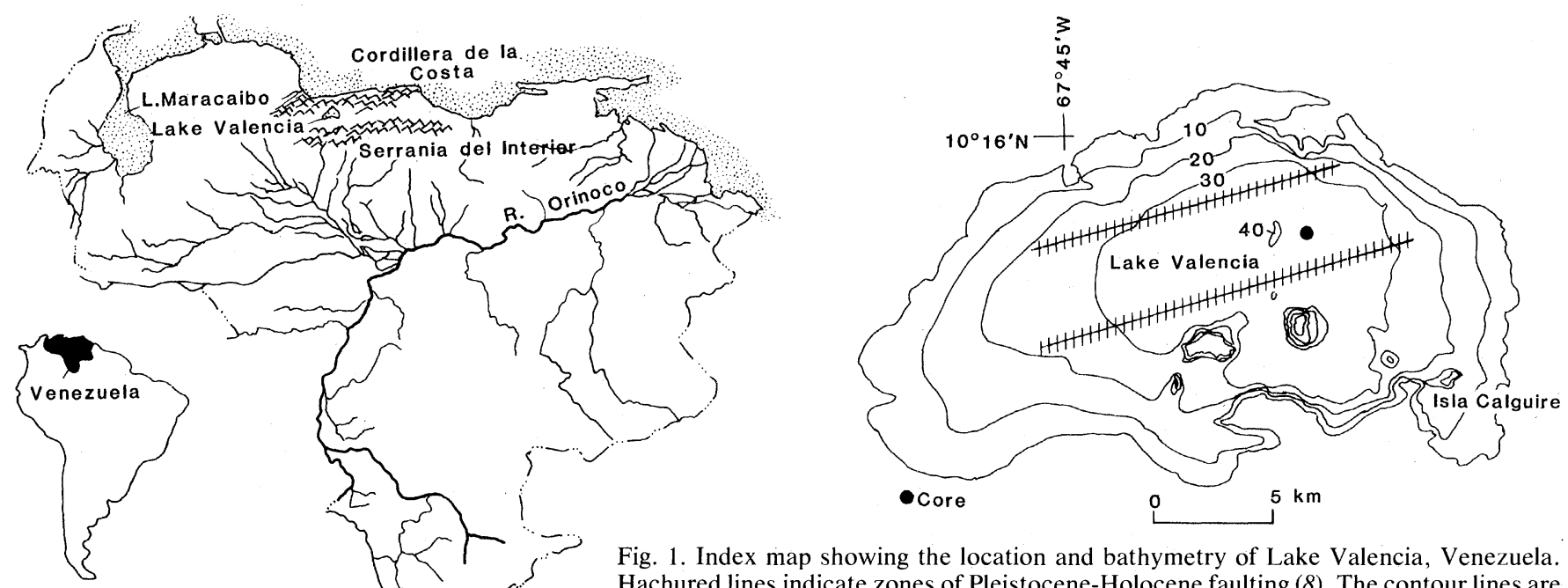

Fig. 1. Index map showing the location and bathymetry of Lake Valencia, Venezuela. Hachured lines indicate zones of Pleistocene-Holocene faulting (8). The contour lines are in meters.
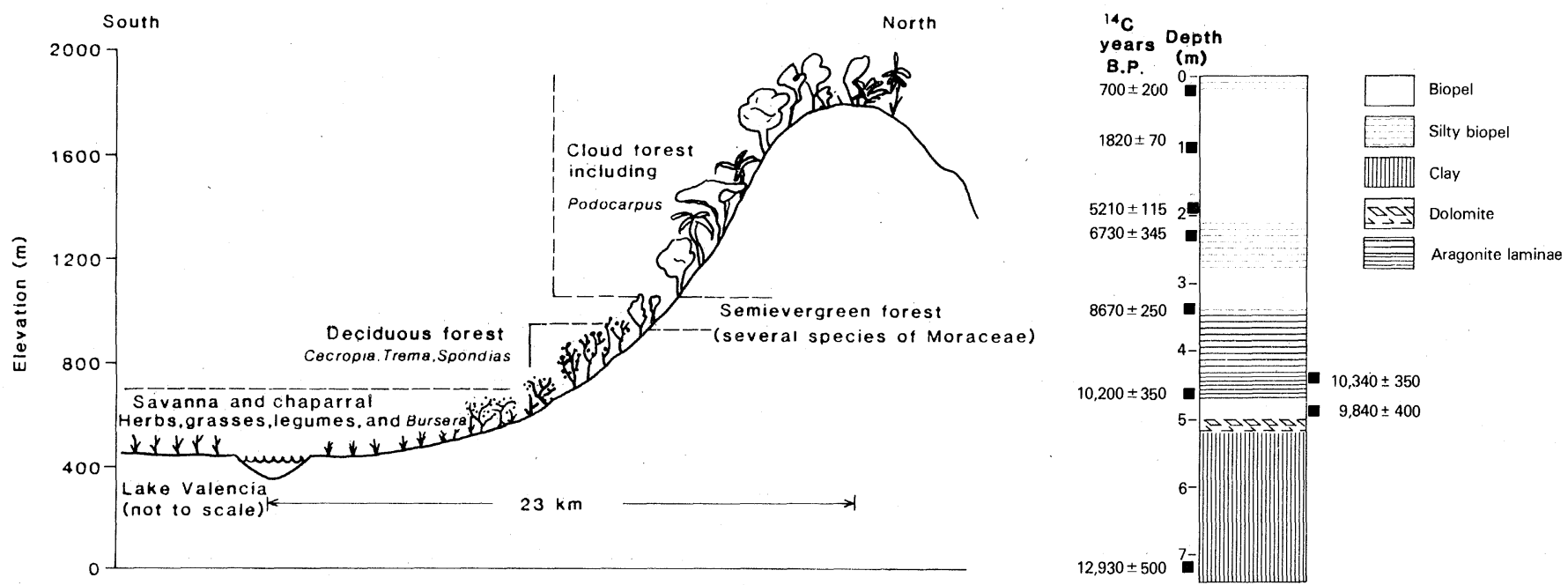

Fig. 2 (left). Schematic representation of the plant communities at Lake Valencia. The species listed in each vegetation zone are those that contribute significant pollen to the lake sediments. Fig. 3 (right). Lithology, stratigraphy, and radiocarbon chronology of the profundal core from Lake Valencia. Anomalous but overlapping dates appear between 4 and $5 \mathrm{~m}$.

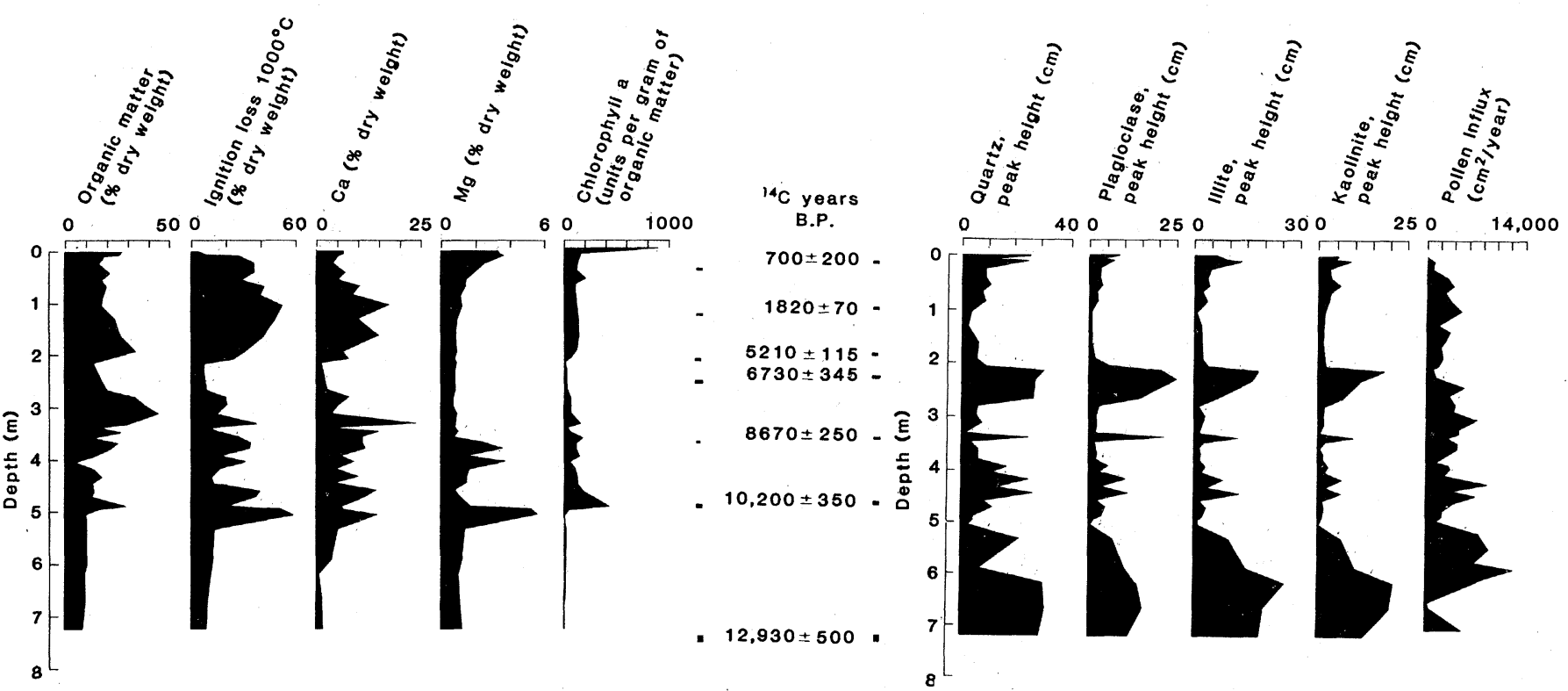

Fig. 4 (left). Selected geochemical profiles from the profundal core, Lake Valencia; analyst, W. M. Lewis, Jr. Fig. 5 (right). Selected clastic mineral components of the profundal core, Lake Valencia; analyst, J. P. Bradbury. Pollen influx is included for comparison; analyst, B. Leyden. 
tions actually persisted during periods of predicted aridity elsewhere.

Our interpretation of the paleoclimatic history of the Lake Valencia Basin is based on analyses of organic and inorganic sediments, diatoms, ostracods and other microfauna, algal remains, and pollen obtained from several lake sediment cores. A deepwater core from near the center of the lake in $37 \mathrm{~m}$ of water (Fig. 1) serves as the primary record for our paleolimnological and paleoclimatic interpretation.

\section{Description, Chronology, and}

\section{Interpretation of the Core}

The core is composed of moderately organic lake muds with variable amounts of carbonate and silicate minerals (Figs. 3 through 6). The basal $2.5 \mathrm{~m}$ of the core consist of calcareous and gypsiferous kaolinite and illite. At a core depth of 5.0 $\mathrm{m}$, there is a distinctive dolomite-rich layer. Above this layer the sediments become more organic (Fig. 4) and are dominated either by carbonates (calcite and aragonite) or by clastic minerals such as quartz, plagioclase, illite, and kaolinite. Discrete laminae of aragonite are present between 4.9 and $3.6 \mathrm{~m}$.

Nine radiocarbon dates establish the depositional chronology of the core (Fig. 3 ), which begins 12,930 years ago and extends to the present. Three radiocarbon dates between 4.6 and $4.9 \mathrm{~m}$ have overlapping ages. For determining influx rates, the date of 10,200 years B.P. at 4.7 $\mathrm{m}$ will be used. The most dramatic lithologic change, from clays below $5 \mathrm{~m}$ to organic marls and silts above this depth, occurred about 10,500 years ago.

The multidisciplinary paleoenvironmental analyses of the core are presented as stratigraphic profiles in Figs. 4 through 12 . The core can be divided into three generalized zones based on the presence or abundance, or both, of characteristic fossils and lithologies.

Zone $1(7.28$ to $5.08 \mathrm{~m} ; 12,930$ to 10,500 years B.P.) extends from the base of the core in clayey sediments to the beginning of organic-rich sediments (Figs. 3, 4, and 5). This zone is characterized (i) by the absence of diatoms, ostracods, and cladocerans (Figs. 7, 9, and 10); (ii) by the presence of Pediastrum boryanum (Fig. 8); (iii) by the dominance of Alternanthera, Cyperaceae, and Gramineae pollen (Fig. 11); (iv) by low values for organic matter and chlorophyll a; and (v) by the absence of arboreal taxa except for occasional pollen of montane taxa (Podocarpus, Juglans, Symplocos) (Fig. 12). The general ab- sence of arboreal taxa is not due to differential degradation, as pollen preservation is reasonably good. Pollen influx varies between high and very low (Fig. 5).

The dominance of Alternanthera (probably $A$. polygonoides, a marsh species of the Venezuelan llanos) in associa- tion with pollen from other semiaquatic plants such as Polygonaceae, Ludwigia, and Typha suggests that marshlike conditions existed in the Lake Valencia Basin during this stage. The lack of diatoms, ostracods, and other aquatic microfossils and the low concentrations of organic matter and chlorophyll deriva-

Fig. 6. Selected authigenic mineral components (peak height in centimeters) of the profundal core, Lake Valencia; analyst, J. P. Bradbury.
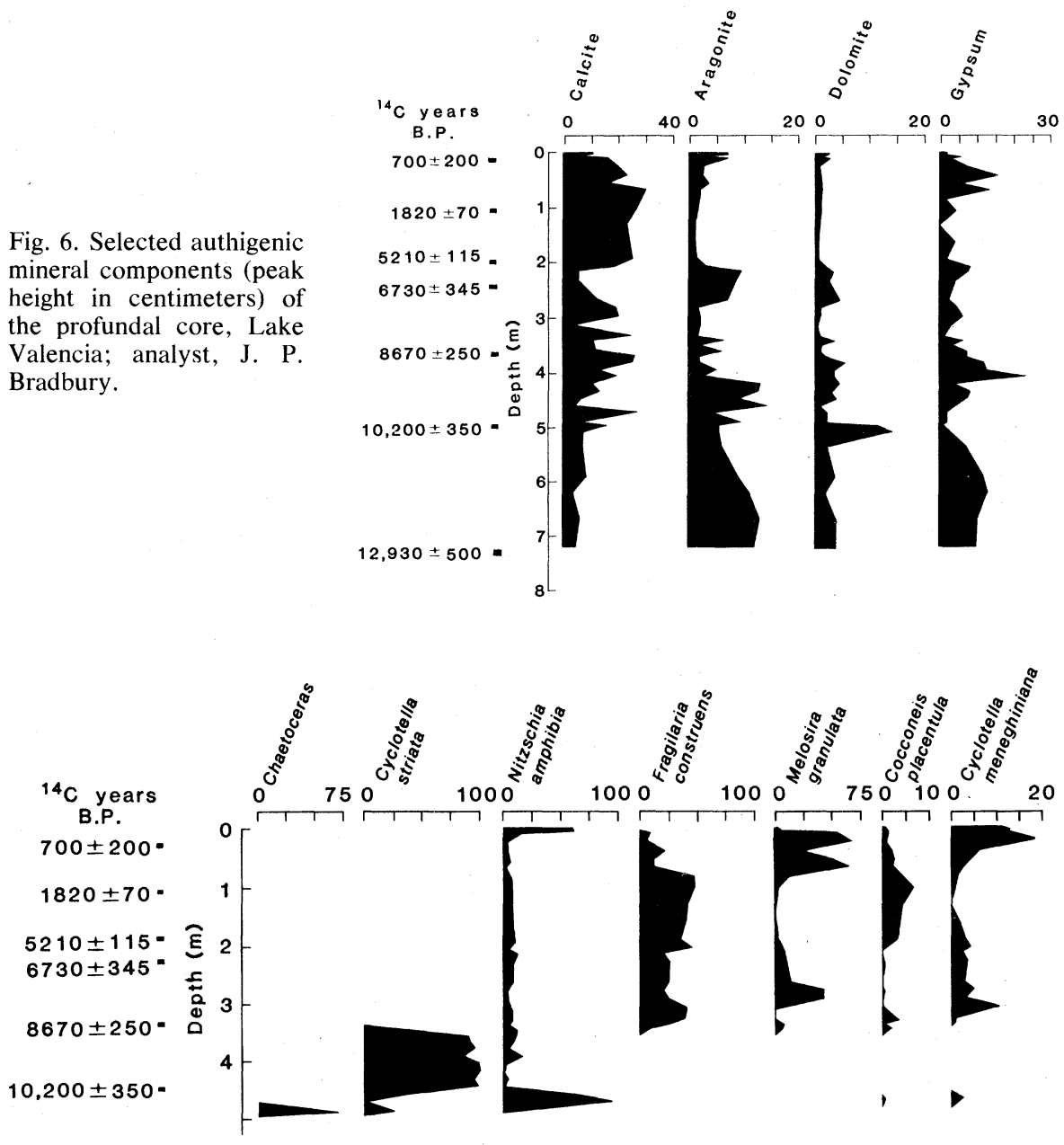

Fig. 7. Selected diatom profiles (in percentages) from the profundal core, Lake Valencia; no diatoms were found below $5 \mathrm{~m}$; analyst, J. P. Bradbury.

Fig. 8. Pediastrum and Botryococcus profiles (in percentages) from the profundal core, Lake Valencia; analysts, B. Leyden and M. Salgado-Labouriau.

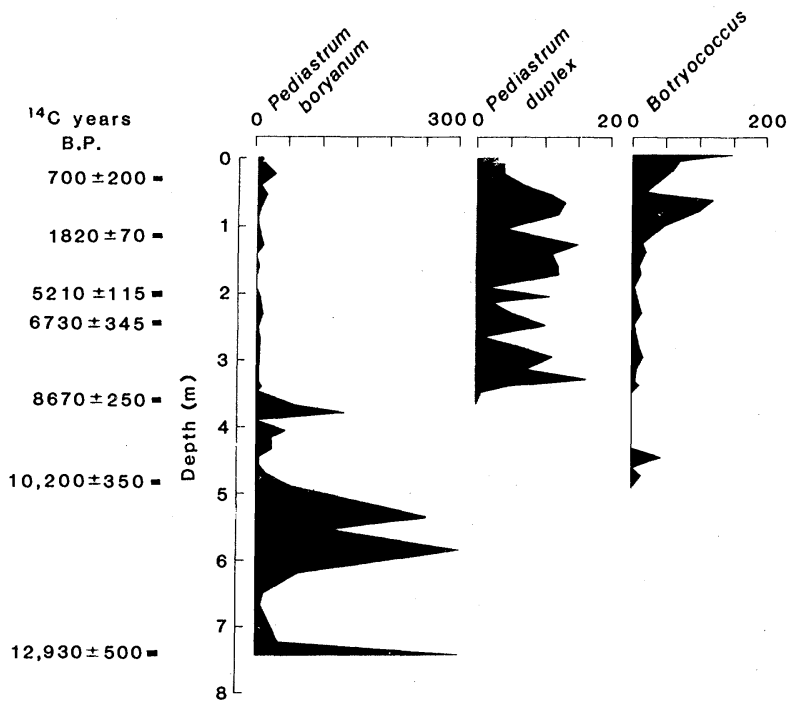



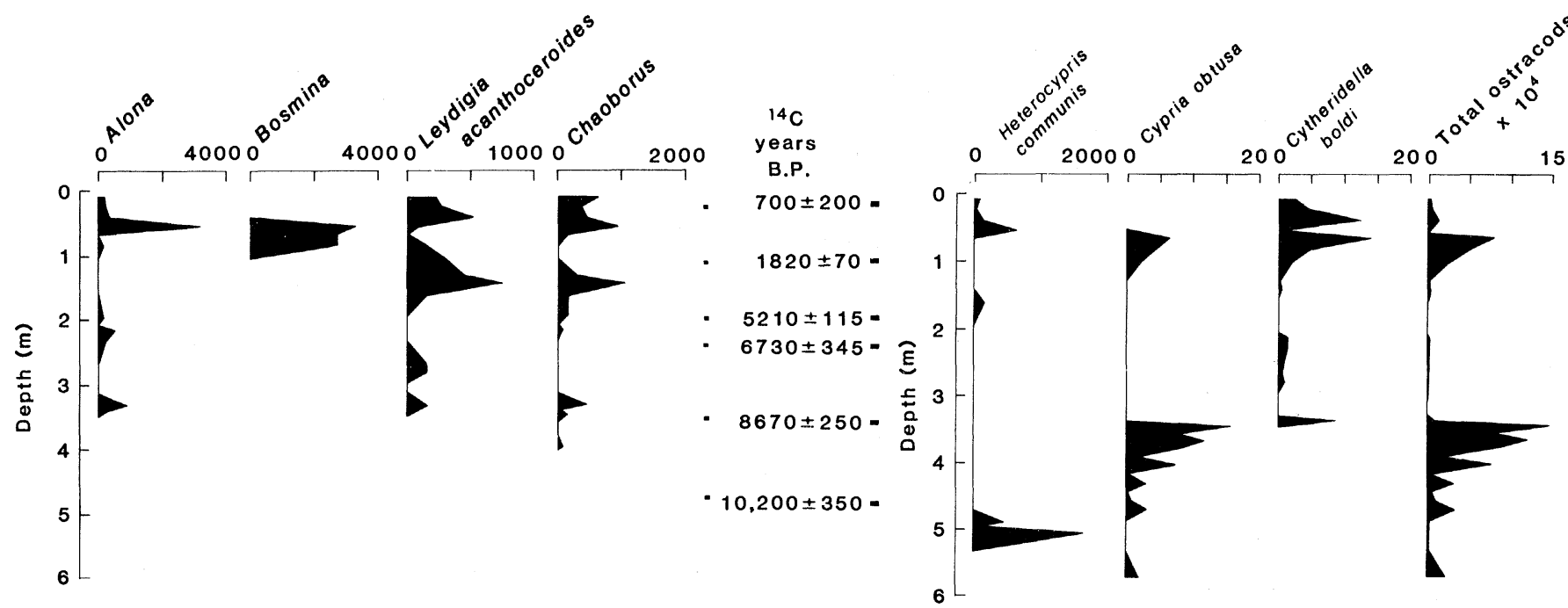

Fig. 9 (left). Cladoceran and dipteran profiles (number per cubic centimeter) from the profundal core, Lake Valencia; no cladocerans or dipterans were found below $5 \mathrm{~m}$; analyst, M. W. Binford. Fig. 10 (right). Ostracod profiles (number per cubic centimeter) from the profundal core, Lake Valencia; no ostracods were found below $6 \mathrm{~m}$; analyst, M. W. Binford.

tives in this zone are consistent with the presence of a marsh environment in which shallow, fluctuating water levels could account for very limited open water and for diagenetic removal of aquatic fossil components.

The ecology of Pediastrum boryanum is not well documented, but this species is evidently tolerant of widely fluctuating environmental conditions and its habitats range from ephemeral ponds to more stable lacustrine systems (10). Its presence in this zone suggests that there was standing water at least from time to time. The abundance of aragonite, gypsum, and dolomite in these clayey sediments (Fig. 6) implies that the marsh was saline at times.

An open xeric herbaceous vegetation is suggested by the maximum influx values of Gramineae pollen (Fig. 11), but the small amount of arboreal pollen (Spondias and Bursera) at a depth of 6.4 $\mathrm{m}$ (Fig. 12) may indicate a minor increase in moisture in what otherwise was an arid climatic period between 12,900 and 10,000 years B.P. $(2,11)$.

Zone 2 (5.08 to $3.50 \mathrm{~m} ; 10,500$ to 8,700 years B.P.) is characterized by an abundant representation of diatoms, ostracods, and other aquatic microfossils, a distinctive lithology of evaporite minerals rich in organic matter and chlorophyll derivatives, and a xeric, herbaceous pollen assemblage that includes a significant representation of arboreal taxa. The diversity of microfossils and the distinctive sedimentology of this zone permit a more detailed paleolimnological and paleoclimatic interpretation than is possible for zone 1 .

The dolomite- and aragonite-rich sediments in the lower part of this zone (5.08 to $4.85 \mathrm{~m}$ ) (Fig. 6) contain high concentrations of organic matter, chlorophyll a, and fungi. The saline-water ostracod $\mathrm{He}$ terocypris communis dominates initially and is joined by planktonic diatoms characteristic of inland saline lakes, particularly Chaetoceras sp. and Cyclotella striata (Fig. 7). Pollen influx is low at this time and consists mostly of littoral herbaceous plants and Ruppia, an aquatic macrophyte characteristic of saline environments.

The microfossil assemblage and sediment characteristics define an initial shallow and productive saline, lacustrine environment. The brief dominance of Nitzschia amphibia, a diatom of eutrophic, freshwater environments, and fluctuating percentages of Botryococcus and Pediastrum boryanum (Fig. 8) apparently reflect variable salinity and nutrient conditions during this early lacustrine phase.

Above $4.85 \mathrm{~m}$ the sediment contains fine laminations of aragonite, and Cyclotella striata dominates the diatom flora. The ostracod Heterocypris communis is replaced by Cypria obtusa, a tolerant swimming ostracod associated with littoral aquatic vegetation. Typha, Compositae, and Gramineae pollen characterize the nearshore plant community (Fig. 11), and arboreal taxa become more abundant in the upper part of the zone.

The aragonite laminae suggest that stratification was maintained for periods sufficient to exclude burrowing organisms that can destroy such delicate sedimentary structures. Extended seasonal stratification is presently characteristic of the lake and leads to an anoxic benthic environment that excludes burrowers (12); a similar mechanism probably ac- counts for the undisturbed nature of the sediments in zone 2. Planktonic diatom assemblages from shallow-water cores indicate that the water was saline and was at least $20 \mathrm{~m}$ deep in the center of the basin shortly after 10,500 years B.P.

In modern lakes, aragonite precipitates at salinities greater than 10 parts per thousand in which the ratio of magnesium to calcium is greater than 12 (13). Such salinities are consistent with the ecological information for the dominant diatom Cyclotella striata, which today occurs in lakes with salinities ranging from 5 to 16 parts per thousand (14).

Arboreal pollen is dominated by early successional taxa in zone 2 (Fig. 12). Bursera dominates initially and is followed by rapid steplike increases in Spondias, Moraceae, Cecropia, and Trema types. These data, coupled with the frequent presence of Rapanea and Melastomataceae pollen, suggest a replacement of the earlier xeric grasslands by a chaparral (lower montane dry forest) followed by a gradual succession toward a semievergreen or deciduous forest. Vegetation associations at higher elevations probably were more mesic. Fluctuations in pollen influx appear to relate to different depositional processes within the lake and to dilution by aragonite, and not to changes in pollen productivity.

In summary, this zone represents the filling of Lake Valencia at the beginning of the Holocene. Initially the lake was surrounded by a halophytic littoral plant association, and salinity was variable. Sparse grassland persisted in the rest of the watershed. The lake rapidly filled, reaching sufficient depth to have a seasonal thermal stratification, but re- 
mained saline. During this phase, an extensive littoral plant association developed as the watershed became forested.

Zone 3 (3.50 to $0.0 \mathrm{~m} ; 8700$ to 0 years B.P.) is characterized by (i) a freshwater assemblage of littoral and planktonic diatoms, (ii) the appearance of the ostracod Cytheridella boldi in association with cladocerans and Chaoborus (Fig. 10), (iii) large amounts of Pediastrum duplex, and (iv) a pollen assemblage dominated by Chenopodiaceae types (Cheno-Ams) (Fig. 11), grasses, and arboreal taxa, resembling the modern assemblages. The sediments consist of rather organic calcareous silts interrupted between 2.1 and $2.7 \mathrm{~m}$ by a layer rich in clastic minerals.

The diatoms and arthropods of zone 3 are all freshwater taxa (Fig. 7). Melosira granulata is an opportunistically planktonic diatom of moderately eutrophic water with a $p \mathrm{H}$ generally between 7 and 9. Cyclotella meneghiniana has similar requirements but is generally more tolerant of higher salinities and nutrient concentrations, and Fragilaria construens is a littoral diatom of broad ecological tolerances. The cladocerans Alona sp. and Leydigia acanthoceroides and the ostracod Cytheridella boldi (Figs. 9 and 10) are muddy-bottom feeders. The relatively low abundances of arthropods and Typha (Fig. 11) suggest deep water with diminished influences from the littoral zone, and the freshwater diatom assemblage indicates that Lake Valencia rose to its spill point and freshened as saline water was flushed from the basin. The pollen assemblage dominated by ChenoAms may reflect fluctuating water levels and conditions unsuitable for the development of a Typha marsh. The strongly fluctuating percentages of arboreal pollen taxa may suggest short-term climatic changes that could correlate with changes in the lake level.

At a core depth of $2.7 \mathrm{~m}$, the sediment mineralogy indicates increased input of clastic sediments to the lake (Figs. 5 and 6) and increased amounts of dolomite and aragonite. These indicate a return to lower lake levels (7). Radiocarbon dates from two shallow-water stromatolite beds on the lake margin and below the spill point provide additional evidence about lake levels during this period. The stromatolite beds (at 418 and $421 \mathrm{~m}$ ) are dated at $5480 \pm 300$ and $7130 \pm 300$ years B.P., respectively, an indication that lower lake levels occurred within the period of increased clastic influx.

The cause of a return to lower lake levels and resulting clastic deposition is unclear. Pollen data reveal no major changes in vegetation or climate that might account for lower lake levels or for increased clastic input (Figs. 11 and 12). Total pollen influx is reduced, presumably by dilution from clastics. Monolete spores and pollen of warm mesophytic plants fluctuate throughout this zone, perhaps in response to variable fluvial input to the lake. Seismic studies (8) indicate that Holocene tectonism occurred, and faulting may have affected depositional patterns in Lake Valencia, although bottom subsidence does not seem likely to account for persistent lower lake levels.

As the effect of increased clastic loading disappears $(2.1-\mathrm{m}$ depth), the dominant diatom flora consists of littoral species Fragilaria construens and Cocconeis placentula (Fig. 7), an indication of extensive but distant littoral environments resulting from higher lake levels. Increased deposition of calcium carbon- ate (Figs. 4 and 6) is consistent with this interpretation (7).

The chronology for these climatic and hydrologic events can be approximated from the radiocarbon dates of the core. The initial trend toward freshness and high lake levels seems to have climaxed by 8000 years B.P. or soon thereafter. Lower lake levels, increased erosion, clastic deposition, and higher salinities in the lake occurred by 7000 years B.P. and lasted until about 6000 years B.P. Afterward, the lake became progressively less saline, overflowing at least intermittently and perhaps continuously. The pollen assemblages of zone 3 are closely similar to the modern pollen input to Lake Valencia and imply the existence of plant associations and a climate generally similar to that of today.

Geochemical and diatom indicators suggest maximum freshness about

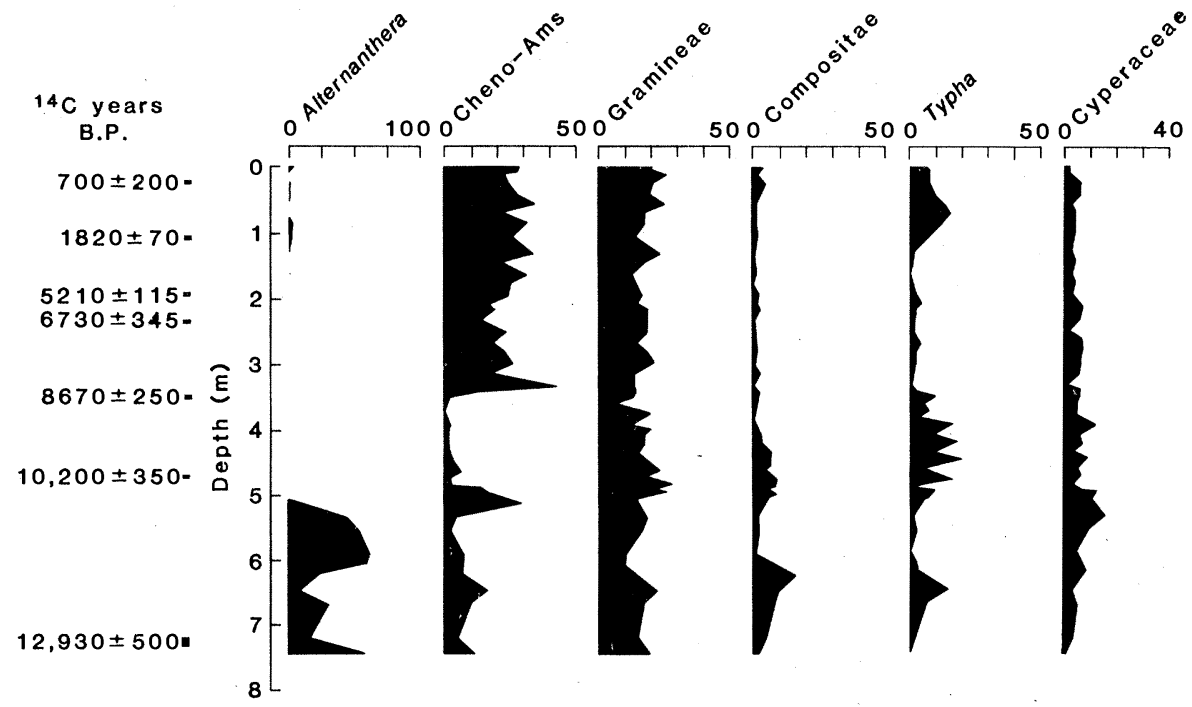

Fig. 11. Nonarboreal pollen profiles (in percentages) from the profundal core, Lake Valencia; analysts, B. Leyden and M. Salgado-Labouriau.

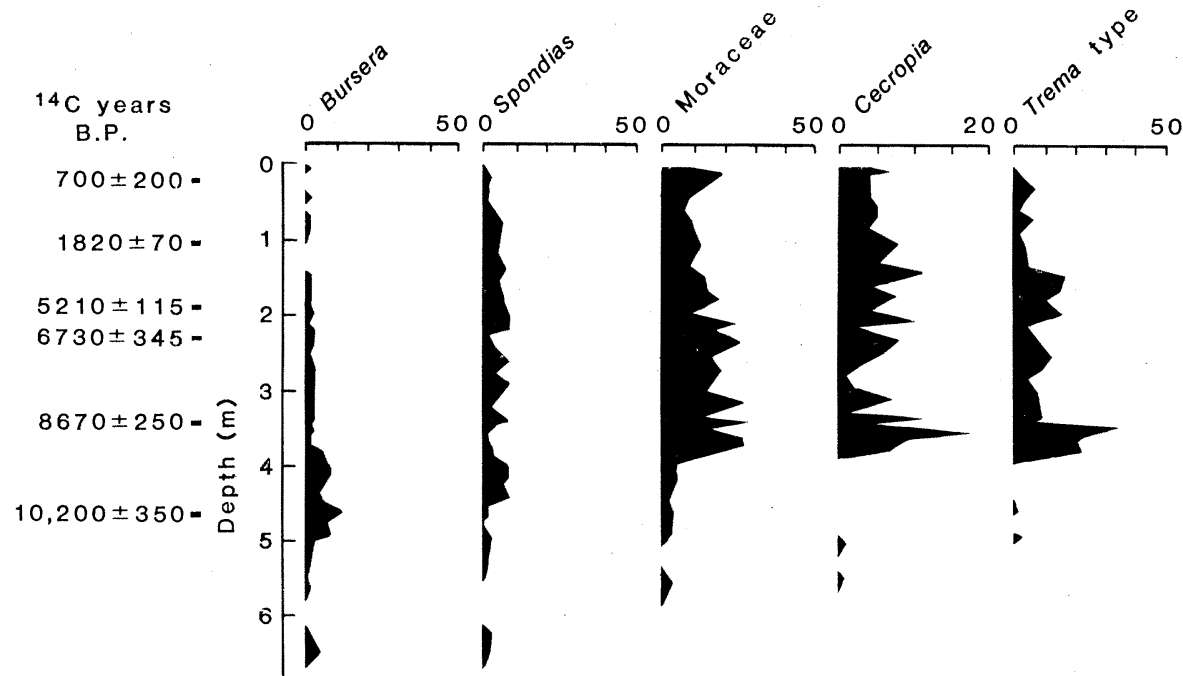

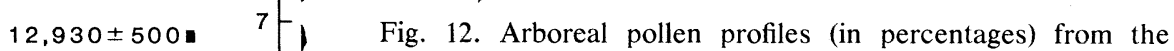
profundal core, Lake Valencia; analysts, B. Leyden and $\mathbf{M}$ Salgado-Labouriau. 


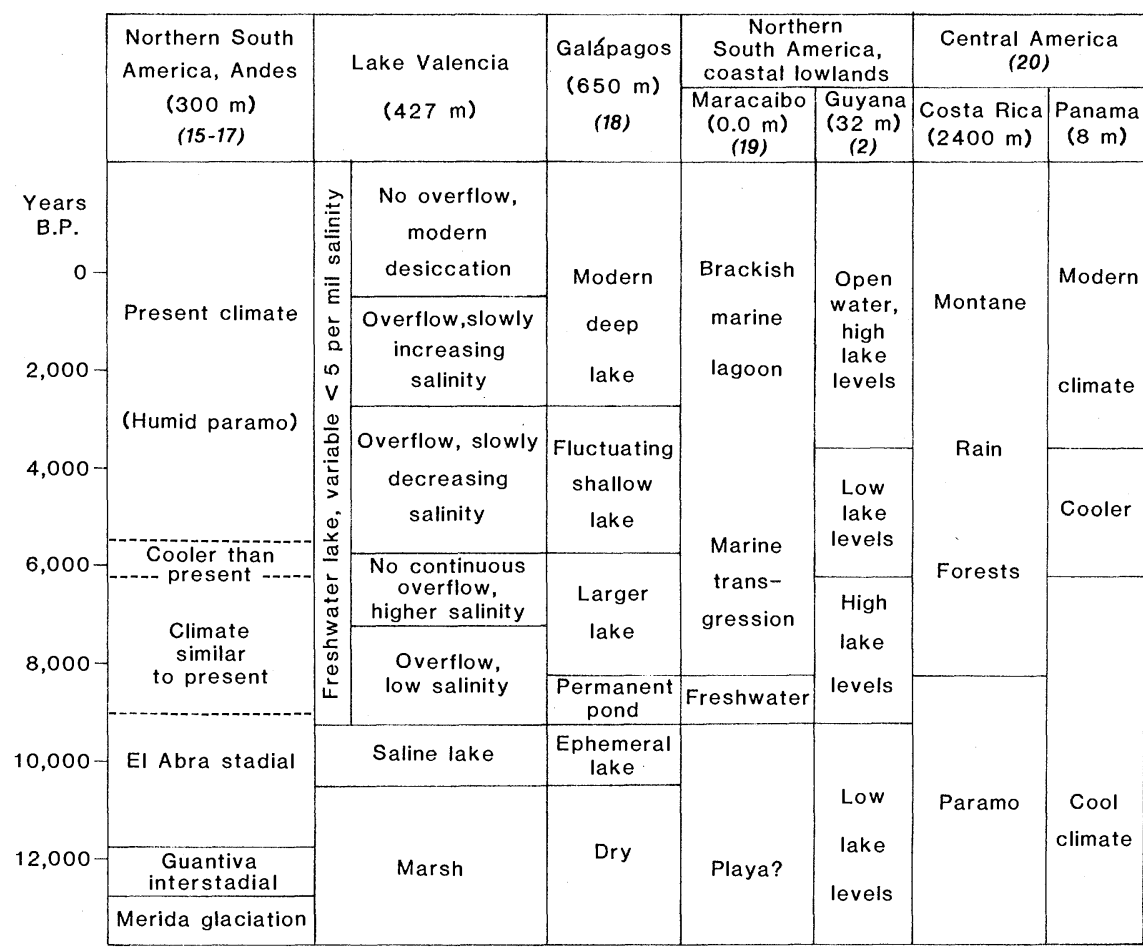

Fig. 13. Tentative correlation of paleolimnological stages of Lake Valencia with paleoenvironmental records from the Galápagos Islands, northern South America, and Central America.

$3000 \pm 500$ years B.P. After this time, the indicators show a slow but definite trend to higher salinities, up to the present. There is a predominance of freshwater planktonic diatoms (Melosira granulata and Cyclotella meneghiniana) and the planktonic arthropod Bosmina, along with high percentages of Typha and Botryococcus, and gradually increasing amounts of clastic minerals. The abundance of Melosira granulata and Bosmina above $1.0 \mathrm{~m}$ suggests increased limnetic nutrients and turbulence at this time; these trends are coincident with geochemical indicators of slowly increasing salinity (Fig. 4). The high percentages of Typha and benthic arthropods imply increased midlake deposition from the littoral zone. Dramatic increases in the diatoms Cyclotella meneghiniana and Nitzschia amphibia (Fig. 7) may indicate increased organic input to the lake, as both diatoms are characteristic of water with high concentrations of dissolved organic material. The increasing amount of clastic mineral matter in the upper portion of the core may represent human disturbance of the watershed, although there is no pollen evidence that unambiguously confirms this. The large quantities of chlorophyll a in the upper levels of the core (Fig. 4) could reflect a lack of pigment destruction in these young sediments, but it is equally possible that they correlate with the diatom indicators of organic enrichment of Lake Valencia. The rapid and distinctive changes in the diatom flora, particularly of Nitzschia amphibia, do not have midHolocene counterparts in deeper levels of the core and thus support the possibility that the most recent changes in Lake Valencia are the result of human activities in its watershed. The contention that man's activities alone are causing the current desiccation of Lake Valencia are not as easily supported in view of the evidence of low lake levels at earlier times during the Holocene history of the lake.

Pollen influx gradually decreases throughout this zone (Fig. 5), but the percentages of arboreal taxa do not change appreciably. This finding suggests that, although the character of the surrounding vegetation was unchanged, perhaps its extent was diminished.

\section{Correlation with Late Quaternary}

\section{Events in Nearby Regions}

The stratigraphic record from Lake Valencia is important because it contains a continuous, well-dated, and well-documented paleoenvironmental history of a low-latitude, low-elevation site from the late Pleistocene to the present. Although well-dated continuous paleoclimatic records are rare at both high and low elevations in northern South and Central America, the Lake Valencia record can be usefully compared to the available paleoenvironmental data for this region.
The principal difficulty is the lack of adequate radiocarbon time control in most studies. Figure 13 is a tentative correlation of paleoenvironmental interpretations from the most relevant records $(15-20)$.

The well-dated paleolimnological record from El Junco in the Galápagos Islands (20) is similar in many respects to the Lake Valencia record (Fig. 13) and suggests that both sites may have experienced the same or similar climates, even though separated by the ocean and the high Andes.

The two most important conclusions from the Lake Valencia study in the context of marine and high-elevation work are the coincidence of the lowelevation aridity with high-elevation glaciation and the correlation of rising sea levels with moist, low-elevation climate. The dry, marshlike conditions at Lake Valencia (from 13,000 to about 10,500 years B.P.) correlate with glacial conditions in the Venezuelan and Colombian Andes at elevations of approximately $3000 \mathrm{~m}$ and with low sea levels and arid climates from the tropical regions of Colombia, Lake Maracaibo, Guyana, and Panama. Logical correlations can also be made with the deep sea record in the Caribbean, which shows lower sea temperatures and arid continental environments $(1,21)$. The increased moisture in the Lake Valencia watershed, beginning about 10,500 years B. P., corresponds to the time of rising sea levels. Paleoenvironmental information of this type provides important constraints and historical baselines for climatic modeling (22).

\section{The Valencia Area as a Possible \\ Pleistocene Refugium}

The Valencia area has been designated as a possible Pleistocene refugium on the basis of the speciation and distribution patterns of a number of diverse organisms (9). The existence of tropical refugia for mesophytic taxa during the Quaternary is generally accepted. However, there has been little confirmation from geological or paleontological studies that appropriate conditions actually existed at the proposed locations.

Our data indicate that the Valencia Basin could not have been part of a refugium, at least during the late Pleistocene. The data conclusively show that the late Pleistocene climates of the Valencia Basin were dry. The possibility remains that a more mesic environment could have existed on the Caribbean side of the coastal mountains to the north of 
Lake Valencia. Such a refugium would have been restricted to a zone of atmospheric condensation similar to the cloud forest association now covering the peaks of these coastal mountains. It would have been much smaller than the originally postulated area and definitely would not have included the Valencia Basin.

\section{Modern Desiccation of Lake Valencia}

There has been considerable discussion of the causes for the desiccation of Lake Valencia during the last 250 years $(3,4,23)$. The paleolimnological data show major fluctuations in the uppermost 10 centimeters of the core, particularly in the diatoms and the geochemical and mineral parameters. Of these, the abrupt decrease of Melosira granulata at a depth of 7 centimeters most likely reflects the onset of historic desiccation. By extrapolation, this change is dated at about 220 years and therefore tentatively coincides with the last recorded observation of overflow. The very rapid recent change can hardly be attributed to extrinsic climatic change, especially since no major climatic changes over the last 250 years are indicated by meteorological data (3). However, geochemical evidence suggests a shift toward higher lake salinities as long ago as 2800 years B.P. (7). The evidence thus suggests that an extrinsic shift toward drier climate has affected the lake, but that the effect has been magnified over the last 250 years by human activity.

\section{Conclusions}

The paleolimnological data from Lake Valencia support the hypothesis that lowland climates in the tropics were arid at the close of the Pleistocene. The Holocene was more humid, but with significant fluctuations in moisture up to the present. Our data add further support to the climatic theories for the tropics that point to the oceans and oceanic air masses as the controlling mechanisms regulating climates on the continental margins. The Valencia data discount the specific designation of the area around the lake as part of a late Pleistocene refugium but leave open the possibility that such refugia did exist on the Caribbean side of the coastal mountains.

\section{References and Notes}

1. E. Bonatti and S. Gartner, Nature (London) 244, 653 (1973); W. L. Prell, Geol. Soc. Am. Bull. 89, 1241 (1978).

2. J. Tricart, Rev. Geomorphol, Dyn. 23, 145 (1974); T. van der Hammen, J. Biogeogr. 1, (1974).

3. A. Bockh, in The Careless Technology, M. T. Farivar and J. P. Milton, Eds. (Natural History Press, New York, 1972), pp. 301-317.

$\rightarrow$ R. E. Crist and C. E. Chardon, Geogr. Rev. 31 430 (1941); M. S. Tamers and C. Thielen, Acta Cient. Venez. 17, 150 (1966).

5. L. Peeters, "Origin y evolucion de la cuenca del Lago de Valencia, Venezuela" (Instituto para la Conservacion del Lago de Valencia, Caracas Venezuela, 1968); "Nuevos datos acerca de la evolucion de la cuenca del Lago de Valencia (Venezuela) durante el Pleistoceno superior y e Holoceno" (Instituto para la Conservacion de Lago de Valencia, Caracas, Venezuela, 1971) Rev. Geogr. Phys. Geol. Dyn. 12, 157 (1970).

6. C. Osgood, Yale Univ. Publ. Anthropol. 92 (1943), entire issue; I. Rouse and J. M. Cruxent, Venezuelan Archaeology (Yale Univ. Press; New Haven, Conn., 1963).

7. W. M. Lewis, Jr., and F. H. Weibezahn, Limnol. Oceanogr., in press.

8. C. Schubert, Catena 7, 275 (1980)

$\rightarrow$ K. S. Brown, Jr., P. M. Shepard, J. R. G.
Turner, Proc, $R$. Soc. London Ser. B 187, 369 (1974); G. T. Prance, Acta Amazonica 3 (No. 3), 5 (1973); B. B. Simpson and J. Haffer, Annu. Rev. Ecol. Syst. 9, 497 (1978); P. E. Vanzolini, in Tropical Forest Ecosystems in Africa and South America: A Comparative Review, B. J. Meggers, E. S. Ayenso, W. D. Duckworth, Eds. (Smithsonian Institution Press, Washington, D.C., 1973), pp. 255-258; Williams, Arq. Zool. 19, 1 (1970); B. S. Vuilleumier, Science 173, 771 (1971).

10. P. Alhonen and S. Ristiluoma, Bull. Geol. Soc. Finl. 45, 73 (1973); S. P. Chu, J. Ecol. 30, 284 $(19: \Rightarrow$ ibid. 31, 109 (1943); M. T. Philipose, Chlorococcales (Indian Council of Agricultural Chlorococcales (Indian Council
Research, New Delhi, no date).

11. M. Salgado-Labouriau, Rev. Palaeobot. Palynol. 30, 297 (1980).

12. This conclusion is based on 5 years of water temperature records from the lake (W. M. Lewis, Jr., and F. H. Weibezahn, unpublished data); the thermal regime is very similar to that of Lake Lar $\Rightarrow[W$. M. Lewis, Jr., Limnol. Oceanogr. 18, $200(1973)]$

13. G. Muller, G. Irion, U. Forstner, Naturwissenschaften 59 (No. 4), 158 (1972).

14. Pyramid Lake, Nevada, 5 parts per thousand total dissolved solids (TDS): Walker Lake, Nevada, 11 parts per thousand TDS; Devil's Lake, vada, 11 parts per thousand TDS; Devil's Lake, TDS.

15. C. Schubert, Boreas 3, 147 (1974); in Moraines and Values, C. L. Schlüchter, Ed. (Balkema, Rotterdam, 1979), pp. 43-49.

16. M. L. Salgado-Labouriau, C. Schubert, S. Valastro, J. Biogeogr. 4, 313 (1977).

17. M. L. Salgado-Labouriau and C. Schubert, $P a$ laeogeogr. Palaeoclimatol. Palaeoecol. 19, 147 (1976).

18. P. A. Colinvaux, Nature (London) 240, 17 (1972).

19. R. Sarmiento and R. A. Kirby, J. Sediment. Petrol. 32, 698 (1962)

20. A. S. Bartlett and E.S. Barghorn, in Vegetation and Vegetational History of Northern Latin America, A. Graham, Ed. (Elsevier, Amsterdam, 1973), pp. 203-299; P. S. Martin, Int. Quat. Congr. (INQUA) 6th Rep. 2 (1964), p. 319

21. F. A. Street and A. T. Grove, Quat. Res. (N.Y.) 12, 83 (1979)

22. W. A. Sanchez and J. E. Kutzbach, ibid. 4, 128 (1974).

23. A. von Humboldt, Voyage aux Régions Equinoxiales du Noveau Continent fait en 1799, 1800. $1801,1802,1803$, et 1804 (Schoell, Paris, 1814).

24. This work was supported by NSF grants DEB 7604300 and DEB 7805324 to W M J DEB Venezuelan Comisión Nacional de In. Jr., by enezuelan. Comision Nacional de Investigacion Cientifica grants to C.S., M.L.S.-L., and F.H.W., and by the U.S. Geological Survey
Climate Program. 